\title{
Helyzetkép az elvándorlásban érintett orvosi szakterületek hazai humánerőforrás-ellátottságáról
}

\author{
Kovács Eszter dr. - Girasek Edmond dr. - Kozák Anna - Sziklai Márta \\ Bélteki Zsolt - György Annamária . Páva Hanna dr. - Szócska Miklós dr. \\ Semmelweis Egyetem, Egészségügyi Közszolgálati Kar, Egészségügyi Menedzserképző Központ, Budapest
}

Bevezetés: Az egészségügyi szakemberek mobilitása, illetve migrációja globális jelenségnek tekinthető. Az Európai Unió szinte minden tagállama rendszerszinten szembesül a munkaerő-áramlás jelenségeivel. Magyarország dominánsan küldő országnak tekinthető, ezért elengedhetetlen az egészségügyi munkaerő folyamatos helyzetelemzése, a tervezés és stratégiaalkotás hazai és nemzetközi szinten.

Célkitüzés: A jelen kutatás célja és újdonsága az, hogy a magyarországi egészségügyi szakember-mobilitási folyamat azon következményét vizsgálja, hogy az elvándorlás milyen demográfiai profilt eredményez az itthon maradó szakember-populációban.

Módszer: Az Állami Egészségügyi Ellátó Központ Emberi Erőforrás Fejlesztési Főigazgatósága Egészségügyi Ágazati Humánerőforrás Monitoring Rendszerének adatbázisából a külföldi munkavállaláshoz szükséges diplomaigazolások kérvényezésének vizsgálatát végeztük el, 2010 és 2017 közötti vizsgálati időszakban, életkor és területi megoszlás szerint.

Eredmények: Hazánkban a mobilitásban érintett szakemberek létszáma az érvényes múködési nyilvántartással rendelkezők létszámához viszonyítva az öt leginkább érintett szakterületen a következőképpen alakult: az aneszteziológia és intenzív terápia esetén a legmagasabb, 23,5\%, a sebészetnél 17,9\%, ezt követi a belgyógyászat 7,9\%-kal, a csecsemő- és gyermekgyógyászat 7,4\%-kal és a háziorvostan 6,4\%-kal. Az eredmények értelmében a mobilitásban érintett öt szakterület szakorvosai legfóképp az 50+ korosztályból kerülnek ki, ezért érdemes és szükséges hangsúlyt fektetni a megfelelő utánpótlás képzésére és megtartására. Az adatok arra is rámutattak, hogy az ellátás esetében markánsak a területi egyenlőtlenségek: a fóvárosi régió, illetve az orvosegyetemi városok, megyék vannak a legjobb helyzetben. Következtetés: Összességében elmondható, hogy a vizsgált szakterületeken a hátrányosabb helyzetű régiókban jellemző az elöregedő szakemberkorfa, illetve az alacsony szakember-ellátottság. A kutatás eredményei hangsúlyozzák az elöregedés problematikáját, valamint a területi diszkrepanciákat a kiáramlással veszélyeztetett szakterületek esetében. Orv Hetil. 2019; 160(31): 1223-1230.

Kulcsszavak: egészségügyi munkaerő-áramlás, mobilitás, elöregedő egészségügyi társadalom, területi egyenlőtlenségek, egészségügyi munkaerő-tervezés

\section{Overview of human resources for health composition in the most mobile specialty groups in Hungary}

Introduction: The Human Resources for Health (HRH) mobility and migration are considered as global phenomena. The European Union often faces the mobility of health professionals on a system level. Hungary is recognised among the sending countries, therefore both international and national level health workforce monitoring, planning, and forecasting are inevitable.

Aim: The purpose of this research was to investigate the national demographical profiles of the medical professions affected most significantly by the Hungarian HRH mobility process.

Method: Age and regional distribution analyses of the requests for degree certificate issued by the National Healthcare Services Centre were carried out between the years of 2010 and 2017.

Results: In Hungary, the rate of mobility - the number of requests for degree certificate among the licensed to practice professionals - resulted in the following: the highest rate was detected in anaesthesiology and intensive therapy with $23.5 \%$, in surgery $17.9 \%$, then internal medicine $7.9 \%$, paediatrics $7.4 \%$, and in general practice $6.4 \%$. According to the results, in the 5 above mentioned professions, the physicians most affected by mobility are mostly from the age 
cohort of 50+. Furthermore, the results also highlight the territorial inequalities: the region of the capital as well as the medical university towns and counties are in the most favourable situation in terms of professional care and supply.

Conclusion: Therefore, it can be concluded that in the case of the 5 investigated subspecialties, not only the overall age of the physicians is higher in the disadvantaged areas, but these regions also have to face a more severe shortage of specialists.

Keywords: health workforce, health workforce planning, mobility, global phenomenon, mobility and migration trends, aging health workforce, territorial inequalities

Kovács E, Girasek E, Kozák A, Sziklai M, Bélteki Zs, György A, Páva H, Szócska M. [Overview of human resources for health composition in the most mobile specialty groups in Hungary]. Orv Hetil. 2019; 160(31): 1223-1230.

(Beérkezett: 2019. január 14.; elfogadva: 2019. március 25.)

\begin{abstract}
Rövidítések
ÁEEK EFF = Állami Egészségügyi Ellátó Központ Emberi Erőforrás Fejlesztési Főigazgatósága; EU = Európai Unió; JA EUHWF $=($ Joint Action on European Health Workforce Planning and Forecasting); WHO = (World Health Organization $)$ Egészségügyi Világszervezet
\end{abstract}

Globálisan és európai szinten is egyre fontosabb téma az egészségpolitikában az egészségügyi munkaerő kérdése. Megfelelő számú és képzettségú egészségügyi szakember nélkül ugyanis nem múködhet (jól) az egészségügyi ellátórendszer $[1,2]$. Az egészségügyi szakemberek mobilitása (mozgás az EU-n belül) és migrációja (mozgás az EU-ba és az EU-ból) számos tagállam nemzeti egészségügyi rendszerére hatással van. Mivel az egészségügyi szakemberek tudása könnyen mobilizálható, és növekszik irántuk a kereslet, szükségszerüen növekedett az egészségügyi szakember-mobilitás nemzetközi volumene. Az egészségügyi munkaerő mobilitása nem egyedi magyar sajátosság, nem egy adott szakmacsoportot érint, hanem globális jelenségnek tekinthető, már hallgatói státuszban is [3-5]. Rendszerszinten számos tagállam szembesül a munkaerő kiáramlásával és/vagy a beáramló szakemberekkel, aminek folyamatos monitorozása részét képezi az egészségügyi munkaerő-tervezési stratégiának [6-9].

A témának kitüntetett figyelmet szentel például az Egészségügyi Világszervezet (WHO), amely több fontos egészségpolitikai dokumentumban hangsúlyozza a szakember-mobilitás körülményeit és következményeit. A WHO „Global Strategy on Human Resources for Health: Workforce 2030" dokumentuma például összefoglalja, hogy milyen célkitűzések és alapelvek mentén javasolt az egészségügyi munkaerő optimalizálása, monitorozása és fejlesztése, valamint hangsúlyozza azt a paradigmát, amely a témának kitüntetett szerepet szán a globális egészségpolitikában. A „WHO Global Code of Practice on International Recruitment of Health Personnel" (a WHO globális magatartási kódexe az egészségügyi dolgozók nemzetközi toborzásáról) pedig az egészségügyi dolgozók nemzetközi toborzására helyezi a hangsúlyt [10]. 2017 szeptemberében Budapesten tartották a WHO Európai Regionális Bizottsági Ülésének 67. ülésszakát, ahol bemutatták a „Towards a sustainable health workforce in the WHO European Region: framework for action" címü dokumentumot, amely iránymutatással és eszközökkel támogatja a tagállamokat a nemzeti szintü munkaerő-tervezésben [11].

Emellett az Európai Unió - ahol a szabad mozgáshoz való jogot alapjogként gyakoroljuk - is felismerte a kérdéskör megkerülhetetlenségét, így már 2005-ben hatályba léptette a diplomaelismerésekkel kapcsolatos direktívát $(2005 / 36 / \mathrm{EC})$, amely az átjárhatóságot szándékozott megkönnyíteni a tagországok között több szektoriális szakmában. A 2007-ben - szintén az Európai Bizottság által - kiadott Green Paper [12] kiemelte az egészségügyi szakember-mobilitás várható hatásait. Az EU több kutatási projektet és egy 3 éves közös fellépést is kiírt a témakör gondozására (JA EUHWF). Példaként említhető a 7-es keretprogramban támogatott Health PromeTHeus [13] projekt, amely a mobilitási trendeket vizsgálta, a MoHProf projekt [14], amely a mobilitás mozgatórugóit vette górcső alá, és az RN4Cast [15], amely az ápolók szakmacsoportjára fókuszált. Jelenleg pedig a „Support for the health workforce planning and forecasting expert network" tender fókuszál a témára (http://healthworkforce.eu/).

Az egészségügyi szakember-mobilitás vizsgálatakor figyelembe kell venni a mobilitás (EU-n belüli) és a migráció (EU-n kívüli) volumenét, valamint a praktizálás céljából realizált éves ki- és beáramlási statisztikákat. A legfőbb trendek szerint a legfontosabb mobilitási irányok a „keletról nyugatra” vándorló szakemberek, a „délről északra” költözők, valamint a határmenti ingázók vagy a határokat rendszeresen átlépők csoportja, akik például egy időben több országban is aktívan végeznek gyógyító tevékenységet, engedéllyel rendelkeznek, és/vagy időszakos ügyeleteket látnak el [16]. A kiemelkedő célországok között tartjuk számon a magas fizetést és életszínvonalat, kiemelkedő fejlődési lehetőségeket kínáló Egyesült Királyságot és a skandináv térség országait, a Benelux államokat, valamint Németországot, Svájcot és Ausztriát $[5,17]$. Az agyelszívásban érintett fó 
küldő országok között az EU keleti országai sorolhatók fel, Románia, Bulgária, azonban a szakemberek kiáramlása Magyarországot is érinti. A jelenség természetesen nem korlátozható az Európai Unióra, hiszen manapság szintén ismert migrációs trend a spanyol ajkú egészségügyi munkaerő Dél-Amerikába való kivándorlása vagy az európai célországok (például Anglia, Németország) egészségügyi dolgozóinak az Amerikai Egyesült Államokba, az ír egészségügyi szakembereknek pedig Ausztráliába való kiáramlása [18, 19].

A kutatási eredményekre építve EU-szinten foglalkoztak még egy átfogó akcióterv kidolgozásával is, amely a mobilitás szerepét hangsúlyozta az egészségügyi emberierőforrás-ellátottság kezelésében, menedzsmentjében [20]. Emellett 2012-ben elkészült egy, az EU összes tagállamát felölelő megvalósíthatósági tanulmány, amely az egészségügyi munkaerő fő kérdéseit, adatokkal való ellátottságát és egészségpolitikai helyzetét elemzi standardizált keretrendszerben/szempontok mentén [21]. A folyamatos elemző munka alátámasztotta, hogy mind a küldő, mind a célországok aspektusából szemlélve kiváltképpen fontos a szakember-mobilitással foglalkozni, mivel az elvándorlás jelentős hiányokat generálhat a hazai ellátórendszerben, amely kihatással lehet az ellátás folytonos és hosszú távú biztosítására [22]. Emellett a célországoknak is szükséges tudniuk, hogy mekkora a beáramlás mértéke, mivel a külföldi munkaerőre utaltság is jelentős kérdéseket vet fel a munkaerő megtervezése, menedzselése során. A Joint Action on European Health Workforce Planning and Forecasting program (JA EUHWF) keretén belül egy 2016-os átfogó riport meghatározta, hogy azokban az országokban, ahol a mobilitás mértéke 5\% feletti, érdemes a munkaerő-vándorlás kérdéskörét beemelni a munkaerő-tervezésbe; ahol viszont ez az arány már 15\% feletti, ott kétségtelen, hogy jelentős egészségpolitikai beavatkozásokra van szükség [6]. Az is nyilvánvaló, hogy mindehhez pontos információra és megfelelő adatokra van szükség. A munkaerőtervezéssel foglalkozó közös fellépés (JA EUHWF) ajánlásokat és jó gyakorlatokat fogalmazott meg arra vonatkozóan is, hogy milyen adattartalmak („Minimum Dataset for Planning”) gyưjtése kívánatos a fenti cél eléréséhez [23].

A mobilitást és az annak következményeképpen előálló hazai egészségügyi munkaerő-ellátottság változását folyamatosan monitorozni kell, és az egészségpolitikai beavatkozások stratégiai tervezésekor számolni kell a mobilitás jelenségével [3]. A mobilitás összetett jelensége alapvetően jól ismert és a szakmai diskurzus fókuszában áll, nem született azonban még olyan írás a magyarországi egészségügyi szakember-mobilitással kapcsolatban, amely a mobilitási folyamat azon következményét vizsgálta volna, hogy az elvándorlás milyen demográfiai profilt eredményez az itthon maradó szakember-populációban, tehát hogy a mobilitás által leginkább érintett orvosi szakmák milyen demográfiai jellemzőkkel bírnak ma Magyarországon.
A jelen cikk célja, hogy a mobilitás által leginkább érintett orvosi szakterületek magyarországi létszámadatait megvizsgálja, valamint életkor és területi megoszlás alapján áttekintést adjon a jelenlegi magyarországi szakember-ellátottságról.

\section{Módszer}

Elemzésünkben az Állami Egészségügyi Ellátó Központ Emberi Erőforrás Fejlesztési Főigazgatósága (ÁEEK EFF) által kezelt Egészségügyi Ágazati Humánerőforrás Monitoring Rendszer adatait használtuk fel.

A vizsgálatban leválogattuk egy hatéves ciklus során keletkezett (2010-2016), a külföldi munkavállalás által leginkább érintett öt orvosi szakterület adatait. Kutatásunkban a szakember-ellátottságot a szakvizsgák mentén mértük. Az adatok között szereplő szakvizsgák az orvosok által használt és érvényes múködési nyilvántartási státusszal rendelkező szakvizsgák.

Mobilitáson, elvándorláson, kiáramláson ebben a tanulmányban a külföldi munka vállalásához szükséges diplomaigazolások kikérését értjük. A mobilitás komplex jelenségének mérése kihívásokkal övezett terület, a mutatók finomításán folyamatosan dolgozik a szakma. A területen jellemző kutatásokban például mérhető a migrációs potenciál, amely a külföldi tervekre kérdez rá. Emellett használható a forrásországban igényelt igazolások számának monitorozása. Kétségtelen, hogy az igazolásigénylések száma a tényleges elvándorlásnak egy korlátozott és nem pontos meghatározása, nemzetközi szinten azonban elfogadott, közeli becslésre alkalmas mérőszámként tartjuk számon. Érdemes megemlíteni, hogy a diplomaigazolások száma nem feltétlenül jelent tényleges, megvalósított mobilitást, tényleges elvándorlást, ezért ezeket az adatokat korlátaik figyelembevételével értelmezzük. A legmegbízhatóbb becslés akkor alkalmazható, ha ismerjük a célországok pontos beáramlási adatait, tehát összevethető a ki- és beáramlási statisztika - azonban e helyütt is számos kérdés merülhet fel, például hogyan interpretáljuk azokat a szakorvosi számokat, ahol több országban érvényes múködési engedéllyel rendelkeznek, viszont gyógyító tevékenységet nem végeznek $[6,24]$.

A leválogatás módszertanát tekintve a leginkább érintett szakterületeket a mobilitásban érintett létszám (fó) nagysága alapján határozzuk meg. Az összes szakorvosi szakterületen megvizsgáltuk a külföldi munkavállaláshoz igényelt diplomaigazolások számát a 2010-2016-os időperiódusra, összegeztük az évenkénti igénylések számát, majd kilistáztuk a top öt szakterületet. A fenti szempontok érvényesítése mellett az adatok leválogatása után a külföldi munkavállalás által leginkább érintett öt orvosi szakterület, amellyel elemzésünkben foglalkozunk: aneszteziológia és intenzív terápia, belgyógyászat, csecsemő- és gyermekgyógyászat, háziorvostan és sebészet. 


\begin{tabular}{|c|c|c|c|c|c|c|c|c|c|c|c|c|c|c|}
\hline & 2010 & 2011 & 2012 & 2013 & 2014 & 2015 & 2016 & 2017 & $\begin{array}{c}\text { Mobil létszám } \\
2010 \text { és } 2016 \\
\text { között* }\end{array}$ & $\begin{array}{l}\text { Vény- } \\
\text { felírás }^{\mathrm{a}}\end{array}$ & $\begin{array}{l}\text { Mobil } \\
\text { létszám } \\
\text { vényírás } \\
\text { nélküil* * }\end{array}$ & $\begin{array}{l}\text { Összes } \\
\text { létszám }{ }^{\mathrm{b}}\end{array}$ & $\begin{array}{l}\text { Mobil* }^{*} / \\
\text { Összes }^{\mathrm{c}}\end{array}$ & $\begin{array}{c}\text { Mobil** / }^{*} \\
\text { Összes }^{\mathrm{d}}\end{array}$ \\
\hline Belgyógyászat & 66 & 80 & 92 & 61 & 51 & 64 & 60 & 44 & 386 & 187 & 199 & 4862 & $7,94 \%$ & $4,09 \%$ \\
\hline Háziorvostan & 60 & 70 & 87 & 72 & 59 & 40 & 42 & 20 & 331 & 180 & 151 & 5148 & $6,43 \%$ & $2,93 \%$ \\
\hline $\begin{array}{l}\text { Aneszteziológia és } \\
\text { intenzív terápia }\end{array}$ & 68 & 59 & 79 & 58 & 53 & 55 & 38 & 24 & 363 & 88 & 275 & 1542 & $23,54 \%$ & $17,83 \%$ \\
\hline Sebészet & 51 & 56 & 51 & 52 & 35 & 42 & 36 & 19 & 254 & 140 & 114 & 1419 & $17,90 \%$ & $8,03 \%$ \\
\hline $\begin{array}{l}\text { Csecsemő- és } \\
\text { gyermekgyógyászat }\end{array}$ & 50 & 36 & 38 & 35 & 32 & 38 & 24 & 24 & 215 & 98 & 117 & 2902 & $7,41 \%$ & $4,03 \%$ \\
\hline $\begin{array}{l}\text { Szakemberek száma } \\
\text { duplikációk nélkül }\end{array}$ & 266 & 277 & 307 & 241 & 216 & 223 & 184 & 125 & 1423 & 614 & 809 & 14345 & $9,92 \%$ & $5,64 \%$ \\
\hline
\end{tabular}

Forrás: Egészségügyi Ágazati Humánerőforrás Monitoring Rendszer - Állami Egészségügyi Ellátó Központ, Emberi Erőforrás Fejlesztési Főigazgatóság

*A mobilitásban érintett szakemberek: a 2010 és 2016 között hatósági bizonyítványt kért személyek száma összesen (egy személyt egyszer számítva abban az esetben is, ha több különböző évben is kiállításra került számára a hatósági bizonyítvány).

A 2010 és 2016 között hatósági bizonyítványt kérők közül a 2017 második felében vényt felírók száma (figyelmen kívül hagyva a pro familia vényírókat).

**A mobilitásban érintett szakemberek száma a vényírók nélkül.

${ }^{\mathrm{b} A z}$ érvényes múködési nyilvántartással rendelkező orvosok száma - 2016. 12. 31.

‘A mobilitásban érintett szakemberek létszáma/Az érvényes múködési nyilvántartással rendelkezők létszáma

dA mobilitásban érintett szakemberek létszáma a vényfelírók nélkül/Az érvényes múködési nyilvántartással rendelkezők létszáma.

\section{Eredmények}

Az 1. táblázat mutatja be a mobilitási volument a 2010 2017-es időperiódusra. Az éves mobilitási számok mellett szerepel az adott szakterületen mobil szakemberek összlétszáma (2010-2016), valamint a 2016-os év teljes létszáma. A táblázatban feltüntettük a 2017-es év második felében vényt felíró orvosok számát, amely megfelelő proxy indikátora lehet annak, hogy a szakember realizálta-e mobilitási szándékát. Továbbá a mobilitás százalékos arányát is megvizsgáltuk, amely a 2016-os összlétszám és a 2010 és 2016 között hatósági bizonyítványt kérvényező mobilitásban érintett orvosok számának, valamint a közülük vényfelíróként a magyar egészségügyi ellátórendszerben a 2017. év második félévében meg nem jelent orvosok számának hányadosa.

Az 1. táblázat alapján jól látszik, hogy az öt szakterület közül arányaiban az aneszteziológia és intenzív terápia szakterülete és a sebészet a leginkább érintett a mobilitásban. Az aneszteziológiai és intenzív terápiás szakvizsgával rendelkező szakorvosok 23,5\%-a, a sebészet vonatkozásában pedig 17,9\% kérvényezett hatósági bizonyítványt a vizsgált időszakban. Amennyiben a vényfelírási tevékenységet is megvizsgáljuk, az aneszteziológiai és intenzív terápiás szakvizsgával rendelkező szakorvosok 17,8\%-a, valamint a sebészek 8\%-a lehet érintett az elvándorlásban. Ez nem jelent ugyan tényleges elvándorlást, azonban érdemes figyelmet szentelni ezeknek a szakterületeknek a munkaerő-megtartási stratégiaalkotásban.
Elemzésünk következő lépésében a Magyarországon múködési engedéllyel rendelkező szakemberekre vonatkozó aggregált adatokat vizsgáltuk. A kiválasztott öt szakterületen dolgozó munkaerő adatait mutatjuk be nem és korcsoport, valamint a munkahely megyéje szerinti bontásban. Az 1. ábrán bemutatott korfán a vizsgált

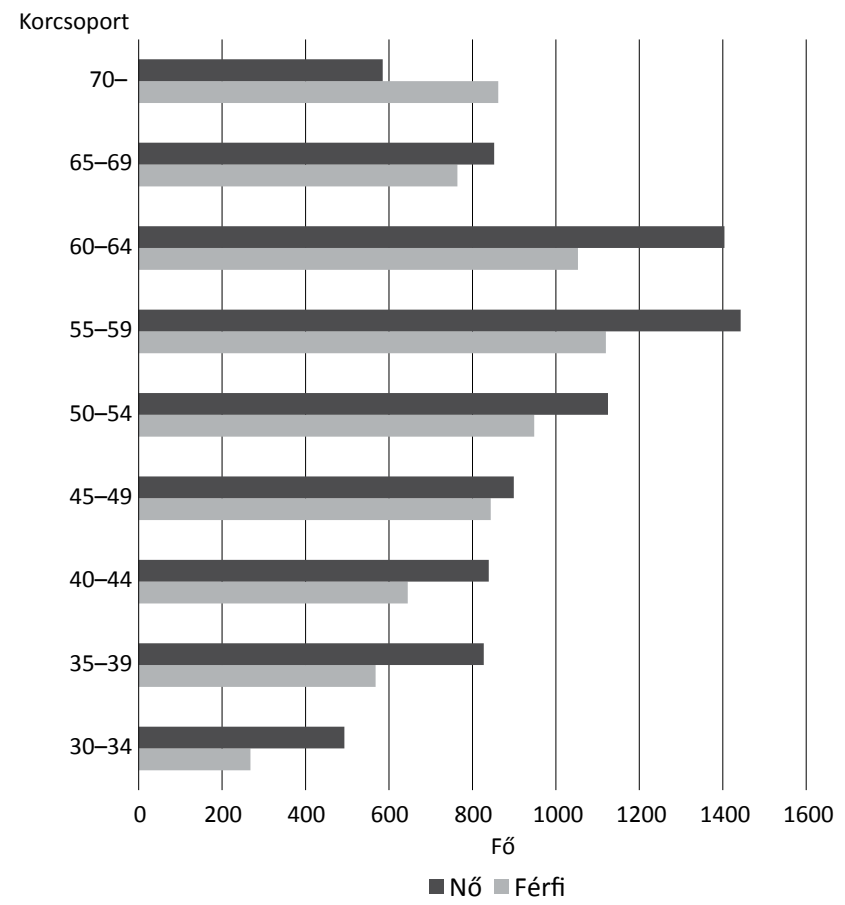

1. ábra $\mid$ Az öt szakterület humánerőforrásának korfája 


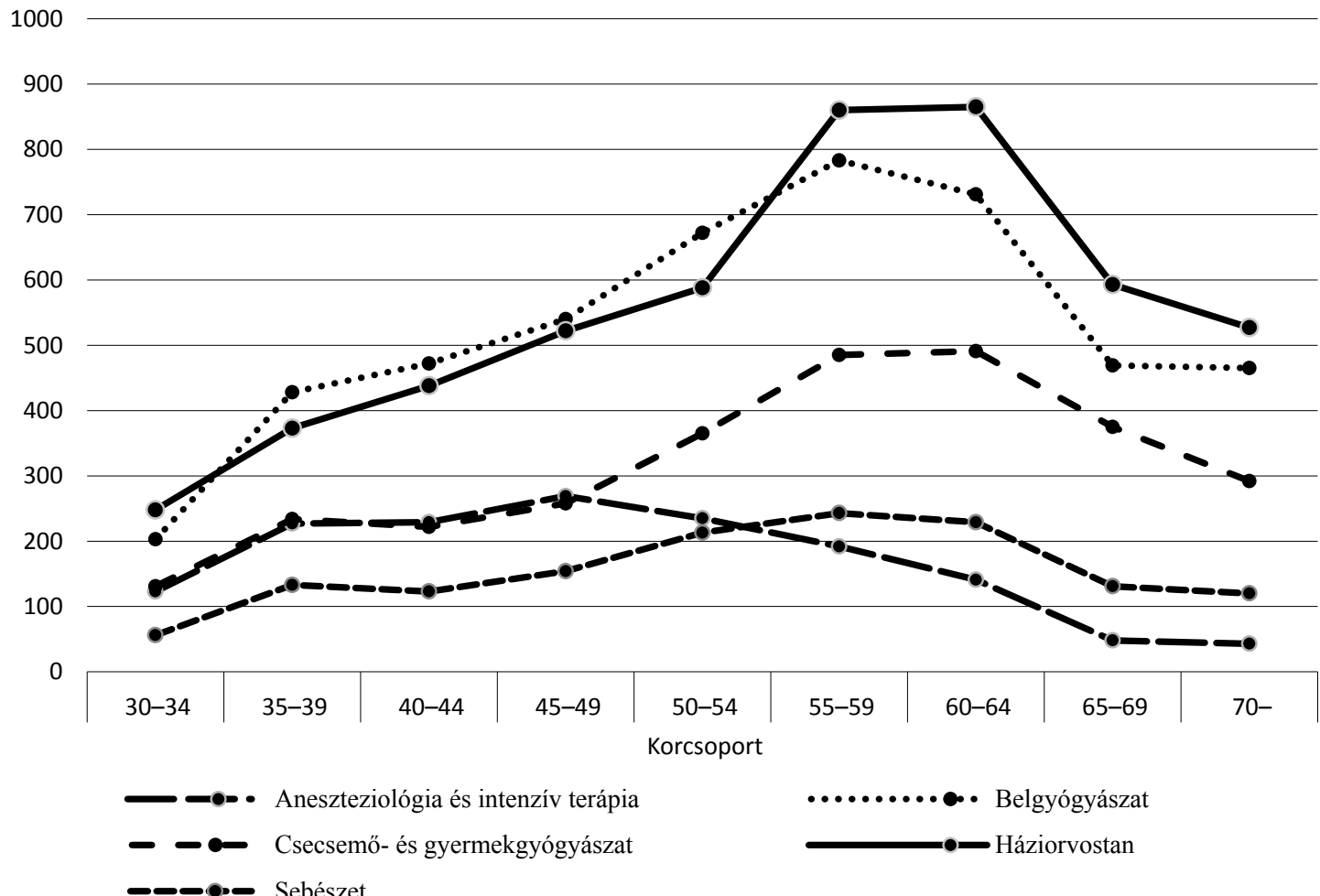

öt szakorvosi csoport együttes kormegoszlása látható. Megállapítható, hogy az 55-59 éves és a 60-64 éves korcsoport teszi ki a legnagyobb létszámú korcsoportot, és a korfán lefelé haladva jelentősen csökkenő létszámokat tapasztalhatunk a 30 év körüli kezdőpont felé. Ez azt jelenti, hogy érdemes hangsúlyt fektetni a munkaerő megtartására és az utánpótlás kinevelésére.

Az adatokból lehetőségünk nyílt elemezni a vizsgált öt szakorvosi csoport megyénkénti összesített - tehát nem szakmákra lebontott - kormegoszlását. A könnyebb interpretálhatóság érdekében az arányszámokat mutatjuk be, azaz hogy az adott megyékben múködő, vizsgált szakvizsgákkal rendelkező szakorvosok közül mennyien vannak 50 éves vagy idősebb életkorban. A vizsgált öt szakmában az 50 év felettiek aránya közel 77\% Nógrád megyében. Ugyanez az arány Jász-Nagykun-Szolnok megyében is $70 \%$ feletti, Komárom-Esztergom megyében pedig majdnem eléri a 70\%-ot, ezt követi Bács-Kiskun és Somogy megye 68\% feletti értékkel. Ebből jól látható, hogy a felsorolt megyékben jelentős az idősebb szakorvosok aránya.

Az egyes orvosi szakmák létszáma, mobilitási volumene, összesített és megyénkénti kormegoszlása mellett rendkívül informatív a korfa szakmánkénti bontásban. A 2. ábrán látható, hogy a belgyógyászati, háziorvostani, illetve a csecsemő- és gyermekgyógyászati szakmában a dolgozók jelentős többsége az idősebb, 50 év feletti korosztályba tartozik. Szintén érdemes megvizsgálni azt, hogy az adott szakmákban dolgozó orvosok hány száza- léka 50 éves vagy idősebb korú, ezzel egyszerúen összehasoníthatóvá válik az egyes szakmák elöregedettsége. A szakterületi bontásban végzett elemzés azt mutatta, hogy a legkritikusabb helyzet a csecsemő- és gyermekgyógyász szakorvosok esetében érhető tetten. A csecsemő- és gyermekgyógyász szakorvosok körében 70\% felett van az 50 éves vagy az annál idősebbek aránya. Ezt követi a háziorvostan közel 68\%-kal, a sebészet kétharmados aránnyal és a belgyógyászat $65,5 \%$-os értékkel. Egyedül az aneszteziológiai és intenzív terápiás szakorvosoknál lehet azt megállapítani, hogy a dolgozó orvosok több mint fele 50 évesnél fiatalabb.

A kormegoszlás mellett fontos információ a területi megoszlás is. Itt azonban az abszolút számok mellett sokkal többet mond a megyék lakosságszámához viszonyított létszám. A 2. táblázatban a 100 ezer lakosra számolt szakorvosi létszámokat mutatjuk be. A táblázatból megállapítható, hogy a szakorvosi ellátottság tekintetében a legjobb helyzetben a fóváros és az orvosegyetemi városok, megyék vannak. Kétségtelen, hogy ezek a területek képzési központok, emellett jelentős szerepet játszanak az adott régió egészségügyi ellátásában is. A fóvárosban a progresszív ellátási csúcsszerep és az orvosképzéshez kapcsolódó intézmények miatt jelentősen magasabb az orvosok létszáma, és szintén az egyetemhez köthető Baranya, Csongrád és Hajdú-Bihar relatív jó helyzete is. A 2. táblázatban kiemeltük az egyes szakmákban az öt legalacsonyabb, lakosságszámhoz viszonyított létszámot mutató megyét. Az adatok alapján 
2. táblázat | Szakorvosok létszáma 100000 lakosra számítva - megyénkénti bontásban

\begin{tabular}{|c|c|c|c|c|c|}
\hline Megye & $\begin{array}{l}\text { Aneszte- } \\
\text { ziológia } \\
\text { és } \\
\text { intenzív } \\
\text { terápia }\end{array}$ & $\begin{array}{l}\text { Belgyó- } \\
\text { gyászat }\end{array}$ & $\begin{array}{l}\text { Csecsemő- } \\
\text { és } \\
\text { gyermek- } \\
\text { gyógyászat }\end{array}$ & $\begin{array}{l}\text { Házi- } \\
\text { orvostan }\end{array}$ & Sebészet \\
\hline Bács-Kiskun & 9,97 & 40,87 & 24,64 & 48,88 & 11,93 \\
\hline Baranya & 20,92 & 60,85 & 38,57 & 66,55 & 21,46 \\
\hline Békés & 8,07 & 36,88 & 21,32 & 43,51 & 8,93 \\
\hline $\begin{array}{l}\text { Borsod-Abaúj- } \\
\text { Zemplén }\end{array}$ & 9,54 & 28,01 & 26,49 & 50,26 & 12,11 \\
\hline Budapest & 26,15 & 90,54 & 42,97 & 53,54 & 23,47 \\
\hline Csongrád & 26,70 & 64,53 & 42,03 & 74,67 & 18,54 \\
\hline Fejér & 11,23 & 39,19 & 22,46 & 45,16 & 9,08 \\
\hline $\begin{array}{l}\text { Győr-Moson- } \\
\text { Sopron }\end{array}$ & 13,62 & 38,22 & 22,19 & 39,98 & 12,74 \\
\hline Hajdú-Bihar & 20,75 & 51,78 & 32,52 & 62,81 & 16,26 \\
\hline Heves & 8,02 & 38,43 & 22,39 & 44,45 & 11,03 \\
\hline $\begin{array}{l}\text { Jász-Nagykun- } \\
\text { Szolnok }\end{array}$ & 8,24 & 30,29 & 23,12 & 45,17 & 10,10 \\
\hline $\begin{array}{l}\text { Komárom- } \\
\text { Esztergom }\end{array}$ & 10,07 & 37,26 & 26,85 & 49,34 & 9,73 \\
\hline Nógrád & 8,25 & 26,81 & 19,08 & 46,40 & 8,77 \\
\hline Pest & 12,72 & 33,78 & 23,90 & 45,77 & 12,47 \\
\hline Somogy & 11,97 & 39,79 & 22,00 & 56,94 & 14,56 \\
\hline $\begin{array}{l}\text { Szabolcs- } \\
\text { Szatmár-Bereg }\end{array}$ & 8,88 & 26,64 & 23,80 & 46,35 & 7,10 \\
\hline Tolna & 11,63 & 29,96 & 21,91 & 45,61 & 7,60 \\
\hline Vas & 12,22 & 40,60 & 21,29 & 53,21 & 11,43 \\
\hline Veszprém & 10,17 & 41,24 & 23,82 & 48,21 & 10,46 \\
\hline Zala & 16,36 & 45,45 & 27,63 & 53,09 & 12,73 \\
\hline
\end{tabular}

Forrás: Egészségügyi Ágazati Humánerőforrás Monitoring Rendszer - Állami Egészségügyi Ellátó Központ, Emberi Erőforrás Fejlesztési Főigazgatóság

megállapítható, hogy súlyos a kiválasztott öt szakterületet érintő szakorvoshiány Békés, Nógrád, Jász-NagykunSzolnok, Tolna és Szabolcs-Szatmár-Bereg megyében a többi megyéhez viszonyítva.

\section{Megbeszélés}

A globális térben zajló egészségügyi munkaerő-mobilitás jelensége nemcsak nemzetközi szinten, hanem nemzeti szinten is jelentős következményekkel jár. Ahhoz, hogy megfelelő számú és képzettségú szakember legyen az egyes tagországok ellátórendszerében, az egészségügyi munkaerő-tervezésnek a mobilitás és migráció jelenségével is számolnia kell [7-10, 21].

Kiváltképpen igaz ez a kijelentés, ha egy adott országot 5-15\% feletti mobilitás érint [6]. Mivel az egészségügyi emberierőforrás-mobilitás a nemzetközi térben zaj- lik, nem fókuszálhatunk csupán a határainkon belüli helyzetelemzésre, azt globális kontextusba kell helyeznünk [11]. Az elöregedés problémája az Európai Unió országait nagymértékben érinti, ami leképeződik az egészségügyi munkaerő területén is. A népesség elöregedése számos terhet ró az egészségügyi ellátórendszerre, így a krónikus betegségek és komorbiditások megszaporodásával az ellátórendszernek és a munkaerőnek is adaptálódnia kell a kihívásokhoz. Az elöregedő orvostársadalom számos más európai ország között hazánkra is jellemző, ami kihatással van az ellátás hosszú távú biztosítására. Az egészségügyi munkaerö-tervezésnek ezért folyamatosan monitoroznia kell a létszámarányokat, jelezni kell a kiáramlásban érintett szakterületeket, és fel kell hívnia a figyelmet az utánpótlásra [7, 10, 25]. A kiáramlásban fontos szerepet játszik a mobilitás, az elvándorlás, valamint a nyugdíjba vonulás és halálozás [22, 23] (vö. „Minimum Dataset for Planning”).

A jelen tanulmányban a mobilitás, elvándorlás által érintett szakterületeket vettük górcső alá, és megvizsgáltuk ezen szakterületek hazánkban tapasztalható demográfiai profilját. Vizsgálatunk hangsúlyozta az elöregedés problematikáját a kiáramlással veszélyeztetett szakterületek esetén, valamint a területi egyenlőtlenségekre is rámutatott. Számos megyében tapasztalható az alacsony szakember-ellátottság, és sok esetben a szakterületen dolgozó kollégák átlagéletkora igen magas, 50 év feletti.

Az egészségügyi munkaerő-tervezés, a létszámadatok monitorozása és a folyamatos elemzés lehetővé teszi az előrejelzések alkalmazását, ami rövid és hosszú távon indikálhatja a szakterületi ellátottság nehézségeit, továbbá egészségpolitikai beavatkozások számára biztosíthat evidenciát. A folyamatos monitorozás mellett érdemes jövőbeli előrejelzéseket készíteni, például megvizsgálni, hogy változatlan demográfiai trendek mellett mennyivel emelkedik az ország orvostársadalmának átlagéletkora, és hogyan jelenik meg mindez a mobilitásban érintett szakterületekre vonatkozóan. Továbbá, változó demográfiai trendek mentén érdemes megbecsülni, hogy milyen következményekkel jár a teljes egészségügyi munkaerő vagy bizonyos szakterületek esetében. Emellett a területi megoszlást, területi egyenlőtlenségeket is figyelemmel kell kísérni.

$\mathrm{Az}$ egészségügyi munkaerő-tervezésnek számos faktort kell figyelembe vennie. A mobilitásban érintett szakmák és a teljes egészségügyi munkaerő kapcsán az adatok gyüjtése és becslések aggregálása mellett célszerü figyelemmel kísérni a mobilitás mozgatórugóit és azok változásait. Az elvándorlás individuális döntésen alapszik, rendszerszinten azonban befolyásolható. A korábbi kutatások szerint a fizetés mellett a munkakörülmények és a munkakörnyezet szervezeti jellemzői igen jelentősen befolyásolják a migrációs potenciált és az elvándorlási terveket. A béremelés vagy az ösztöndíjprogramok [26, 27] bevezetése fontos lépés a hazai egészségpolitika részéról, emellett azonban több faktor befolyásolására is lenne lehetőség. Magyarországon a többlépcsős béreme- 
lés hozzávetôlegesen 30\%-os béremelkedést [27] mutatott 2010 és 2015 között. A béremelés mellett az ösztöndíjprogramok bevezetése kiemelkedő lépés a munkaeró-megtartási stratégiában. A vizsgált szakterületek tekintetében három ösztöndíjprogram is releváns, viszont a Markusovszky Lajos- (2011-tól), a Méhes Károly- (2012-től) és a Hiányszakmás (2015-től) ösztöndíjak közül egyidejúleg egy vehető igénybe. A Markusovszky-programban 2011 és 2015 között például több mint 3000 szakorvosjelölt vett részt, a Méhes- és Hiányszakmás ösztöndíjakban további 350 szakorvosjelölt vett részt. Az említett munkaerő-megtartási intézkedések mellett érdemes a célzott munkaerő-megtartási törekvéseket figyelemmel kísérni az agyelszívásban érintett országokban és az európai jó gyakorlatokat adaptálni Magyarországon $[28,29]$.

Végül fel kell hívnunk a figyelmet az olyan munkaerőmegtartási stratégiára is, amely az e-health és $\mathrm{m}$-health térnyerésébőll eredeztethető. Az e-health és m-health által kínált megoldások számtalan haszonnal járhatnak az alacsony munkaerő-ellátottságú területeken. Az ellátásszervezés és a betegútmenedzsment szempontjából a telemedicina útján megvalósított e-konzultáció, e-leletezés vagy az $\mathrm{m}$-health nyújtotta lehetőségek, az okoseszközök által vezetett állapotkövetés betöltheti azt a támogató szerepet, amely az esetleges átmeneti munkaerőhiányból fakad. A telemedicina lehetőségeinek integrálása az ellátásszervezésbe és a betegútmenedzsmentbe megoldásokat kínálhat az egyenlőtlen munkaerő-ellátottság és/vagy -hiány kiegyensúlyozására.

Anyagi támogatás: A közlemény megírása és a hozzá kapcsoló kutatómunka anyagi támogatásban nem részesült.

Szerzői munkamegosztás: K. E., G. E., B. Zs., Gy. A. közösen alakították ki a közlemény fókuszában álló téma megjelölését, és közösen határozták meg a közlemény elemzési tervét. G. E. és K. E. végezte az adatelemzést, és részt vettek a kézirat megszövegezésében. K. A. és Sz. M. a kézirat szerkesztését és referenciáinak ellenőrzését végezte. B. Zs. és Gy. A. az elemzés ellenőrzését, valamint a kézirat lektorálását végezték. P. H. és Sz. M. részt vett a cikk végleges változatának kialakításában. A cikk végleges változatát valamennyi szerző elolvasta és jóváhagyta.

Érdekeltségek: A szerzőknek nincsenek érdekeltségeik.

\section{Irodalom}

[1] WHO. Working together for health: World Health Report 2006 Popul Dev Rev. 2006; 32: 790-791.

[2] Elmer D, Endrei D, Ágoston I, et al. Changes in the number of physicians in the health care system of European countries. Value Health 2018; 21 (Suppl 3): S175.

[3] Győrffy Zs, Szél Zs. Willingness to work abroad among Hungarian medical students. [Magyarországi orvostanhallgatók külföldi munkavállalási szándékai.] Orv Hetil. 2018; 159: 31-37. [Hungarian]

[4] Pónusz R, Kovács D, Raposa LB, et al. Motivations of foreign employment and carrier change among Hungarian physiotherapists. [Külföldi munkavállalás és pályaelhagyási indítékok a magyar gyógytornászok körében.] Orv Hetil. 2016; 157: 342-349. [Hungarian]

[5] Kovács D, Pónusz R, Boncz I, et al. Survey of the Hungarian health care practitioners' economic-migration and career changing attitude. Value Health 2018; 21(Suppl 1): S115.

[6] Aszalós Zs, Kovács R, Eke E, et al. Health workforce mobility data serving policy objectives. Available from: http://healthworkforce.eu/wp-content/uploads/2016/03/160127_WP4_ D042-Report-on-Mobility-Data-Final.pdf 2016 [accessed: March 25, 2019].

[7] Kovács E, Kovács R, Aszalós Z, et al. Report on Health Workforce Planning Data - Preparing for tomorrow's meaningful actions. Joint Action on European Health Workforce Planning and Forecasting, Budapest, 2016.

[8] Kovács R, Eke E, Kovács E, et al. The applicability of the WHO Global Code of Practice on the International Recruitment of Health Personnel within a European context. Joint Action on European Health Workforce Planning and Forecasting, Budapest, 2015.

[9] Kovács R, Girasek E, Kovács E, et al. Managing intra-EU mobility - do WHO principles of ethical recruitment have relevance? Hum Resour Health 2017; 15: 78.

[10] WHO CC on HRH Development. WHO Global Code of Practice on the International Recruitment of Health Personnel. [A WHO globális magatartási kódexe az egészségügyi dolgozók nemzetközi toborzásáról.] Budapest, 2017. [Hungarian]

[11] WHO Regional Office for Europe. Towards a sustainable health workforce in the WHO European Region: framework for action EUR/SC24(4)/12. World Health Organization, Geneva, 2017.

[12] EC. Green Paper: Modernising the professional qualifications directive. European Commission, Brussels, 2011.

[13] Wismar M, Maier CB, Glinos I, et al. Health professional mobility and health systems: evidence from 17 European countries. World Health Organization, on behalf of the European Observatory on Health Systems and Policies, Copenhagen, 2011.

[14] Tjadens F, Weilandt C, Eckert J. Mobility of health professionals. Health systems, work conditions, patterns of health workers' mobility and implications for policy makers. MoHProf Group, Heidelberg, 2013.

[15] Aiken LH, Sloane DM, Bruyneel L, et al. Nurse staffing and education and hospital mortality in nine European countries: a retrospective observational study. Lancet 2014; 383: 1824-1830.

[16] Buchan J, Wismar M, Glinos I, et al. Health professional mobility in a changing Europe. New dynamics, mobile individuals and diverse responses. Observatory Studies Series, Brussels, 2014.

[17] Szekanecz Z, Tóth Z, Hamar A, et al. Why would doctors from Debrecen go abroad? Results of a questionnaire. [Miért mennek/mentek külföldre a debreceni orvosok? Egy felmérés eredményei.] Orv Hetil. 2017; 158: 1458-1468. [Hungarian]

[18] Hernandez S, Sanabria Mora H, Tonaco Borges F, et al. Análisis comparado de experiencias de gestión de flujos migratorios de profesionales de la salud. Escuela Andaluza de Salud Pública, Granada, 2016.

[19] Te V, Griffiths R, Law K, et al. The impact of ASEAN economic integration on health worker mobility: a scoping review of the literature. Health Policy Plan. 2018; 33: 957-965.

[20] EC. Commission staff working document on an action plan for the EU health workforce. European Commission, Brussels, 2012.

[21] EC. EU level collaboration on forecasting health workforce needs, workforce planning and health workforce trends - a feasibility study. European Commission, Brussels, 2012; p. 172. 
[22] Malgieri A, van Hoegaerden M, Michelutti P. Handbook on health workforce planning methodologies across EU countries. Joint Action on European Health Workforce Planning and Forecasting, Rome, 2015.

[23] Michelutti P, Leonardi G, Malgieri A. Minimum planning data requirements for health workforce planning. Joint Action on European Health Workforce Planning and Forecasting, Rome, 2014.

[24] Aszalós Z, Kovács E, Kovács R, et al. Terminology gap analysis. Joint Action on European Health Workforce Planning and Forecasting, Budapest, 2014.

[25] WHO. Global strategy on human resources for health: Workforce 2030. World Health Organization, Geneva, 2016.

[26] Eke E, Kovács E, Cserháti Z, et al. Addressing health workforce outflow in Hungary through a scholarship programme. Eurohealth (Lond). 2016; 22: 38-41.
[27] Health Registration and Training Center, Hungary. Annual re port on the HRH situation of health care sector in 2015. [Egészségügyi Nyilvántartási és Képzési Központ - Beszámoló az egészségügyi ágazat humánerőforrás 2015. évi helyzetéről - az egészségügyi ágazati humánerőforrás-monitoring rendszer alapján.] Budapest, 2016. [Hungarian]

[28] Barriball L, Bremner J, Buchan J, et al. Recruitment and retention of the health workforce in Europe. Directorate General for Health and Food Safety European Commission, Brussels, 2015.

[29] Kroezen M, Dussault G, Craveiro I, et al. Recruitment and retention of health professionals across Europe: a literature review and multiple case study research. Health Policy 2015; 119: $1517-1528$.

(Kovács Eszter dr., Budapest, Kútvölgyi út 2., 1125 e-mail: kovacs.eszter@emk.sote.hu)

\section{Romhányi Orvostalálkozó - Lelkigyakorlat (manréza) orvosoknak Szár, 2019. augusztus 31. Moderátor: Prof. Dr. Szelényi Zoltán}

\section{Délelőtti program \\ goo Szentmise \\ $10^{00}$ Üdvözlések \\ Németh Norbert (polgármester) \\ Prof. Dr. Kellermayer Miklós: „Gyógyszer az örökhalál ellen”}

$10^{30}$ Márfi Gyula (veszprémi érsek): A betegség hordozása és gyógyitása - mint szakrális cselekedet

$11^{00}$ Legeza József (teológus, görög katolikus parókus): A magyar görögkatolikus egyház története, helyzete

$11^{30}$ Rieger Tibor (szobrászművész): A művészet szellemi alapjai a Koronázó palásttól napjainkig

Romhányi-emléktábla megkoszorúzása

\section{Délutáni program}

$14^{00}$ Prof. Dr. Poór Gyula: A kórház legyen több, mint kórház

$14^{30}$ Prof. Dr. Losonczy Hajna: Az immunglobulin profilaxis jelentősége krónikus lymphoid leukémiában

$15^{00}$ Prof. Dr. Emődy Levente: Romhányi György klinikopatológiai szemléletének példája az utódgenerációk számára

$15^{30}$ Prof. Dr. Kondákor István: A hívő orvos

Genzwein Ferenc sírjának megkoszorúzása

A cikk a Creative Commons Attribution 4.0 International License (https://creativecommons.org/licenses/by/4.0/) feltételei szerint publikált Open Access közlemény, melynek szellemében a cikk bármilyen médiumban szabadon felhasználható, megosztható és újraközölhetö, feltéve, hogy az eredeti szerző és a közlés helye, illetve a CC License linkje és az esetlegesen végrehajtott módositások feltüntetésre kerülnek. (SID_1) 